New Zealand Journal of Industrial Relations, 20(1): 1-22

\title{
From Rigid to Flexible Employment Practices in UK Commercial Television: A Case of Government-Led Reform
}

\author{
John Trevor Campling*
}

The article locates the forces precipitating the radical changes in employment practices in British Commercial Television since the mid 1980 s and proceeds to discuss the various dimensions of these employment reforms from a "flexible firm" perspective. It is argued that perceived pressure from government, rather than from the product market, triggered the unilateral imposition by management of "flexible" employment practices. In addition, key industrial events in British commercial television, such as the dissolution of national, multiemployer collective bargaining arrangements and the strike and lockout at TVam, combined with the numerous changes to national labour relations legislation, shifted the balance of industrial power to management. This allowed "flexible" practices to be introduced more rapidly and without disruptive opposition from the broadcasting unions. Whilst the new "flexible" employment arrangements have reduced labour costs dramatically in the shortterm, some of the practices are inconsistent, resulting in employee morale and product quality problems. With governments in New Zealand and Australia pursuing a variety of policies to inject greater "flexibility" and less regulation into product markets, labour markets and work places, they should pay close attention to the lessons that can be learnt from the British commercial television experience. The impact upon productivity, work practices, and employment levels of politically instigated employment change is of importance to any industry facing such circumstances. It is also contributes to the wider debate on the origins and nature of employment flexibility and changes in industrial relations.

\section{Introduction}

This article deals with two main issues: the origins of flexibility, and the nature of the flexible practices introduced. The British commercial television broadcasting industry has recently undergone a series of dramatic changes to its employment relationship. These changes have arguably transformed the industry from a "bastion of restrictive practices" to a model of employment "flexibility". This article examines the forces that promoted change within the industry, the "flexible" employment practices that resulted, and the impact upon 
the different stakeholders in the industry. The early sections of the article will examine the extent to which political rather than economic forces were decisive in precipitating the emergence of new employment practices. In other words, the political contingency is seen as the main motor of change, rather than altered product markets. This argument contrasts with the widely held view that economic contingencies have driven the transformation of employment relations (e.g. Marchington and Parker, 1990; Kochan, Katz and McKersie, 1986).

On having demonstrated that "political" rather than "economic" contingencies were primarily driving employment changes in the industry, the article then turns to an analysis of the extent and nature of the "flexible" employment practices introduced. The analysis demonstrates that, while managements have introduced various types of "flexible" practices, not all these practices are compatible.

The analysis builds upon the "flexible firm" model that was developed by Atkinson and others in the mid-1980s (Atkinson 1984, 1987; Atkinson and Gregory, 1986; Atkinson and Meager, 1986; Rimmer and Zappala, 1988). The model argues that organisations increasingly demand and achieve greater flexibility from their workforce. Flexibility can take a variety of forms, and in Atkinson's original model included functional, numerical and financial forms, although these have been refined and expanded upon by subsequent authors. For example, Rimmer and Zappala (1988) distinguish five types of flexibility: external numerical, internal numerical, functional, wage, and procedural. The first two correspond with Atkinson's numerical flexibility, while wage flexibility corresponds generally with financial flexibility, which is intended to encourage the development of the various numerical flexibilities and functional flexibility. Procedural flexibility is an extension to the "flexible firm" model.

In accordance with Atkinson's and Rimmer and Zappala's "flexible firm" model, it is suggested that in the case of British commercial television "flexibility' was pursued in a "strategic" manner, rather than as a piecemeal or fragmentary intervention. There are several reasons for this. First, the rapid deregulation that the Government promised to introduce made many companies acutely concerned about their short-term survival. Consequently, most immediately drew up strategic plans to introduce many of the major elements of the flexible firm model. Managements from four different companies actually made direct reference to Atkinson's flexible firm model, stating that it was the basis for their employment changes. Second, the incumbent television franchise holders recognised that most of the new companies that would compete for their franchises would adopt highly flexible, and relatively low cost, employment regimes. The incumbent franchise holders believed that fragmentary or piecemeal change would not allow them to react quickly and extensively enough to the intended lower labour cost strategies of their franchise competitors.

The article will conclude with an assessment of the extent to which changes in the various components of the employment relationship actually amount to a "transformation" of the industry's employment relations, and of the impact upon various stakeholders in the industry. 


\section{Commercial TV and the politics of regulatory change}

The "political contingency" explanation of employment change rests upon the idea that it was government pressure and the threat of deregulating the domestic television market, rather than actual product market change, that stimulated and drove the employment changes in British commercial television. To help illustrate this, it is necessary to briefly review the recent political history of commercial television broadcasting in Britain.

From its inception in 1956 until the early 1980 s, British commercial television was provided by the Independent Television (ITV) network, which held the only licence to provide commercial broadcasting in the United Kingdom. By the 1980s the network had grown to 14 regionally based television companies which coordinated everything from programme scheduling to collective bargaining through the Independent Television Association (ITVA) - the network's employer association. ITV shared the airwaves with the public, noncommercial broadcaster - the British Broadcasting Association (BBC).

This duopolistic system, with its unique combination of public and private influences, was criticised by the Trade Union Congress (TUC) in the 1970s for being biased against the black community, strikers and socialists, and by advertising companies for allowing ITV a monopoly over television advertising. By the late 1970s an unusual coalition of supporters from the left wing programme-makers, who were seeking alternatives to the "centre-ground" of the duopoly, and free market crusaders, who wanted greater entrepreneurship in order to break the "comfortable duopoly", was able to persuade the Annan Committee (1977) to endorse the creation of a fourth channel (Davis and Levy, 1992). However, Channel Four was established and developed along the principles of public service broadcasting and the ITV companies successfully lobbied to sell the channel's advertising airtime in return for paying an annual levy to the channel. The advertising monopoly therefore remained intact.

By the mid 1980s the debate over television regulation was divided among three main approaches: neo-liberalism, neo-mercantilism, and neo-pluralism (Dyson and Humphreys, 1990). The Thatcherite neo-liberalist view justified the values of competition on the basis of the pervasive and inescapable demands of international technological and market rationality associated with the emerging information society. For neo-liberalists, markets are superior to politics for satisfying audience (consumer) demand, as argued in the Peacock Report (1986).

The neo-mercantilists, on the other hand, believe in the pursuit of "economic statecraft" in the interests of national wealth, power and identity. This belief in the supremacy of politics over markets was championed from the 1920s by Lord Reith, the first Director General of the BBC, and largely went unchallenged as the "correct" way to regulate television broadcasting until the $1980 \mathrm{~s}$.

The neo-pluralist perspective maintains that broadcasting policies are shaped by extremely complex configurations of international and domestic pressures within which institutional structures and policy networks play a crucial role (Dyson and Humphreys, 1990).

From the early 1980 s the neo-liberal perspective gained considerable support from the 
government, with Prime Minister Thatcher strongly endorsing the market-led approach, at least in principle. The most influential and closely argued analysis of this neo-liberalist model was provided in the Peacock Report. Peacock highlighted five major criticisms of British broadcasting: first, the inefficiencies of the "comfortable duopoly" of the ITV and $\mathrm{BBC}$; second, the inflation of broadcasting costs caused largely by the monopoly position of the ITV companies; third, the arrogance and complacency of the $\mathrm{BBC}$; fourth the absence of consumer sovereignty and cost-effective programme provision; and fifth, the preoccupation with the idea of broadcasting as a pure public or social good in perpetuity, irrespective of technological change. For Peacock, freedom of entry for any programmemaker and the ability of viewers to register their preferences directly would allow market forces to be unleashed.

Inspired by neo-liberal ideology and a rejection of corporatism, the Thatcher government began its campaign to deregulate broadcasting, at least in theory. The four major initiatives taken by the government between 1987 and 1991 promised a "brave new world" of deregulated broadcasting, but ultimately delivered a regulated system with the BBC and ITV maintaining their commanding position in the industry (Davis and Levy, 1992). While the BBC and ITV have undoubtedly been exposed to greater market forces it was the newcomers such as British Satellite Broadcasting, Sky, and numerous medium sized independent production companies that suffered greatest from market forces. Institutional inertia and intense lobbying by the ITV companies preserved the status quo. Whilst the government modified the franchise rules and regulations, it did not deregulate the product market through reducing barriers to industry entry, and did not reduce its control over programme content for Channel Three (formerly ITV).

This institutional continuity contrasts sharply with the dramatic transformation of the industry's employment relations and labour market institutions since 1987. The government's threat of marketisation, which acted to pressure managements into securing employment changes, produced a government-led rather than market-led employment transformation. ITV companies were responding to a "political contingency" rather than direct economic contingencies (Ferner, 1985).

The government's motives for threatening "marketisation" on the industry are tied closely to its publicly declared desire to abolish restrictive employment practices and to deliver greater managerial control to managements through weakening trade union influence. The government's frustration with ITV's willingness to maintain restrictive practices and tolerate substantial trade union control in the industry produced a government response designed to threaten the financial security of the companies. Marketisation would erode monopoly rents from advertising and force cost reductions on the companies. The threat of deregulation was sufficient to initiate fundamental changes to employment practices, such that by the time the government's new broadcasting bill was introduced to Parliament the industry was acting as if marketisation was imminent or had already occurred. The threat of product market deregulation precipitated the collapse of national, multi-employer collective bargaining arrangements and triggered the protracted industrial action at TVam. These events, in turn, accelerated the pace of employment reform throughout ITV.

Before turning to the industrial relations and labour market changes, the government's major regulatory initiatives will be examined briefly. The first major intervention came 
shortly after a seminar for television executives held in Downing Street in 1987 in which Prime Minister Thatcher described ITV as the last bastion of restrictive practices in British industry. The government announced that by 1992,25 percent of programmes shown on ITV and BBC had to be made by independent production companies. The aim was to provide greater programme-making opportunities for independent companies, many of whom were non-unionised. The support for independent production companies had two aims: first, the reduction of inflationary industry costs; and second, the weakening of the broadcasting unions through increased casualisation.

The second government initiative was the announcement of a Monopolies and Mergers Commission inquiry into labour practices in the television and film industries. Since the early 1980 s the government had resorted increasingly to using the Fair Trading Act and the Monopolies and Mergers Commission to reduce the influence of trade unions. The Commission's findings, published in April 1989, cleared the broadcasting unions of operating restrictive practices against the public interest, concluding that most alleged restrictive practices had been eliminated and that those remaining, mostly involving agreements for actors and musicians, were not against the public interest (Monopolies and Mergers Commission, 1989). The government delayed the publication of the report for over four months and suggested at one stage that it would not be made available publicly. While the report failed to deliver the stinging indictment of "irresponsible" trade union practices that the government had anticipated, it did instil a greater sense of urgency into ITV and BBC management to change working practices, and it increased pressure for union compliance.

The government's third initiative was the publication of the White Paper on broadcasting in November 1988 (Home Office, 1988). The Peacock Report's recommendations influenced the White Paper's proposals for the auctioning of ITV regional licences to the highest cash bidder, the establishment of a new "lighter-touch" regulator for the ITV, the creation of a fifth television channel, and a statutory minimum of 25 percent of ITV and $\mathrm{BBC}$ programming from independent companies. The White Paper and the MMC inquiry combined to create a "crisis climate" within ITV. While the government's proposals appeared unstoppable, the ITV companies moved quickly to implement changes in the one area where they believed the tide was turning in their favour - industrial relations and labour market practices.

The White Paper paved the way for the 1990 Broadcasting Act, which resulted in a major reorganisation of the ITV network. From 1993, ITV would be known as Channel Three with ten year regional licences awarded to the highest bidder with the most financially viable business plan that passed a quality threshold assessed by the newly created Independent Television Commission. The auction process had been modified to give greater emphasis to programme quality, such that the Commission had considerable latitude to select lower bids in order to preserve quality programming on the network. In 50 percent of the franchise decisions, the Independent Television Commission selected a lower bid (Campling, 1992). The ethos of public service broadcasting was upheld by the Commission in the same way that its predecessor had - the Independent Broadcasting Authority. Indeed, with the creation of a Channel Three central scheduler's office of 50 staff, to select the best programme ideas from Channel Three and the independents, there seems to be a reappearance of complex regulation, but in a more centralised form. The new institutional and 
regulatory arrangements demonstrate the continuity, rather than discontinuity, with British broadcasting's past.

From 1988 to 1991 , the ITV companies were wrestling chiefly with the threat of marketisation. Whilst the merger of BSB and Sky to form BSkyB heightened fears about future satellite penetration of the terrestrial television market, the ITV still maintained a virtual monopoly of airtime advertising revenue in 1992. While government rhetoric advanced notions of regulatory reform and the unleashing of competitive forces, in reality new forms of more centralised regulation emerged in television broadcasting. The government's neo-conservatism undermined the deregulatory market-led prescriptions of neo-liberalism.

\section{Forms of "flexibility" in commercial television}

The government-led, rather than market-led, transformation of industrial relations and labour market practices in commercial television has been exceptionally rapid, heralding a new era of "flexibility" in the industry. ITV managers argue that the major objective of "flexibility" is to increase overall firm stability and preparedness to cope with government and product market initiated changes. Approximately 10 percent of these believe that flexibility is also essential for internally driven (pro-active) change, as well as reactive responses.

While some of the different types of flexibility are inconsistent, such as increased management control of staffing and increased procedural flexibility, the number of potential combinations and the specific forms flexibility can take are numerous (Sayer and Walker, 1992). The existence of these differences makes the identification of particular models of flexibility premature.

Not only are different types of flexibility inconsistent, there are a number of the disadvantages associated with individual forms of "flexibility", as noted by Pollert (1988; 1991) and Harvey (1989) in a range of industries. Evidence from commercial television suggests this sector is no exception. Problems in maintaining employee loyalty, the erosion of disciplinary power over a growing freelance workforce, and reduced ability to control labour costs of freelance workers under "tight" labour markets are the major employer problems that "flexibility" can bring. At present, UK commercial broadcasters only face difficulties in eliciting worker commitment to more "flexible" working practices.

Rimmer and Zappala's flexibility typology, which includes external numerical, internal numerical, functional, wage, and procedural flexibility, will be used to examine the changes in British commercial television's industrial relations and labour market practices since 1988. The Rimmer and Zappala model provides a convenient typology for gauging overall "flexibility".

The following discussion of "flexible" employment practices is based upon data collected from 15 of the 17 ITV companies and all the broadcasting unions between 1987 and 1992 . Much of the information was obtained through structured and semi-structured interviews with line staff, supervisors, middle managers and some executive level managers. Two short 
questionnaires were also employed to capture data on shifts in the level and composition of labour in all the companies.

\section{External numerical flexibility}

External numerical flexibility is where an organisation adjusts its levels of labour inputs to meet changes in demand. This includes increased use of workers employed by subcontractors, specialised self-employed workers, and staff supplied by temporary employment agencies. Also included are the enterprise's own employees who have no career status, for whom redundancy and re-employment are linked to economic conditions, who have temporary employment contracts or are part-time or casual workers, and who have positions with high turnover rates where the numbers employed can easily be reduced by a policy of attrition (Benko and Dunford, 1991).

Prior to the late 1980 s, the ITV staffed for peak production demand with predominantly permanent staff. The "comfortable duopoly" allowed substantial organisational slack to be sustained without seriously affecting the financial viability of the industry. The annual company reports for the ITV companies, combined with employment data from two surveys conducted by the author in 1989 and 1991, reveal that in 1985 the 17 firms in the ITV network employed 15,750 permanent employees with an additional 1,200 freelance full-time equivalents (or seven percent of total employment). By 1991, there were 11,305 permanent employees, a reduction of 28 percent, with an additional 2,150 freelance full-time equivalents (or 19 percent of total employment), an increase of 80 percent over the 1985 level. Estimates of ITV employment at the beginning of the new franchise period (January 1993), based upon information in the franchise bids and from company employment projections, reveals a further decline in permanent employment and continued growth in freelance labour. For January 1993, there were 8,900 permanent employees, a reduction of 43 percent over 1985, and 2,200 freelance full-time equivalents or 25 percent of total employment. Figures 1 and 2 illustrate the magnitude of this shift in the composition of employment in ITV.

At Central, Tyne Tees, Thames, and Grampian Television, over 50 percent of the permanent workforce were retrenched between 1985 and 1992. Three of the ITV companies - Ulster, Scottish and Anglia Television - kept their retrenchments below the 25 percent level. The magnitude of the job reductions for individual companies is positively related to the size of their programme-making operation and the extent to which management operated tightly staffed. Of the "Big Five" ITV companies, those dominating network programming, Thames, Central, and LWT shed half of their permanent staff, while Yorkshire (YTV) and Granada retrenched a third. 
Figure 1: Freelance employment as a percentage of full-time employment in ITV, 1983 to 1991

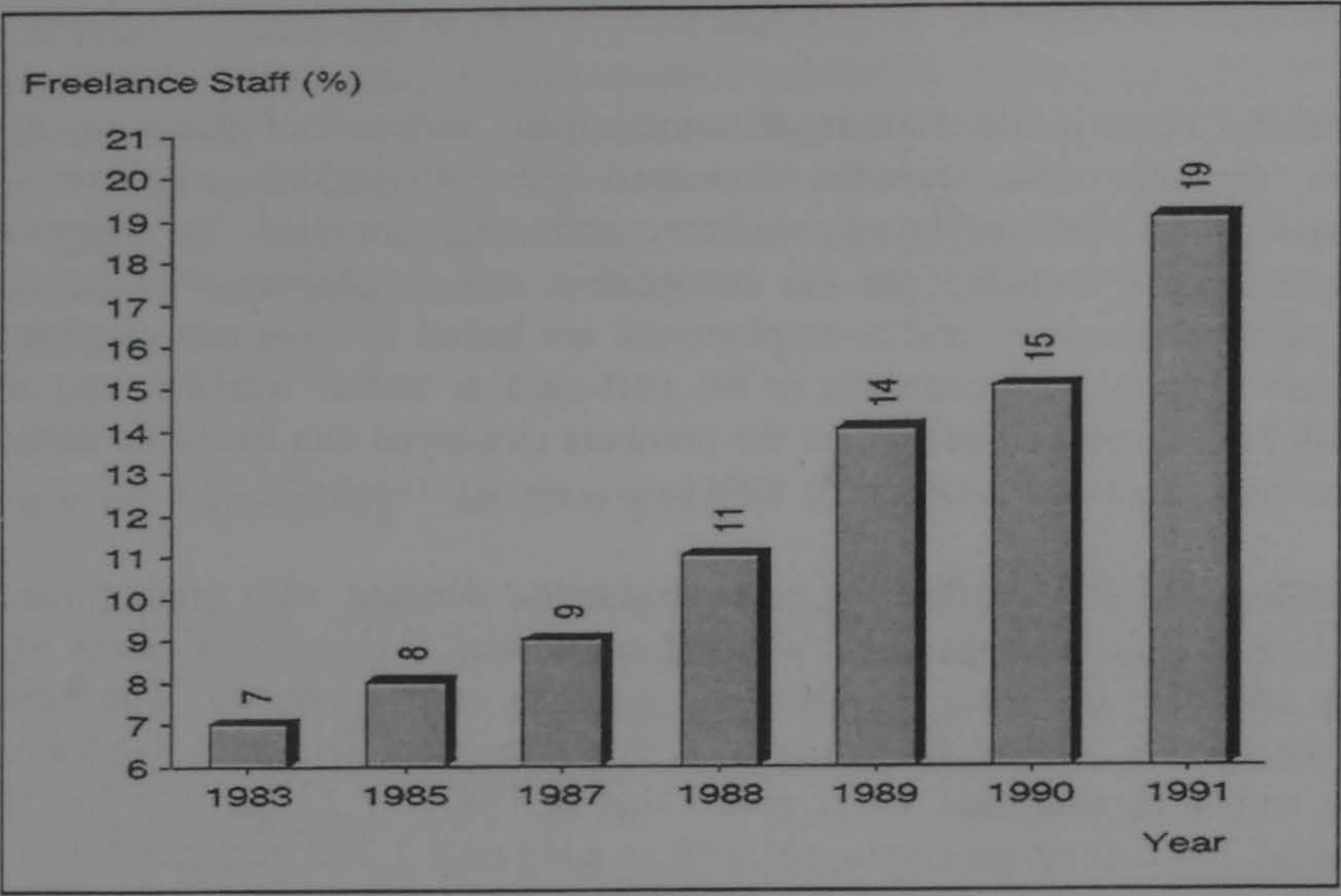

Source: Information obtained from ITV companies from two surveys administered by the author in 1989 and 1991, from company annual reports, from interviews with industrial relations and personnel directors/managers, and from newspapers and trade journals.

Those companies with substantial programme-making operations had greater scope for either introducing greater external numerical flexibility or for work intensification. They were forced to retrench more heavily in those departments because of the government's 25 percent independent quota. Drama and documentary departments have always had highly seasonal fluctuations in business activity, yet peak production staff levels were maintained because, firstly, national collective agreements penalised companies for using freelance workers; secondly, the broadcasting unions had always made permanent employment a high priority; thirdly, the companies needed a ready supply of skilled production staff; and lastly, their advertising monopoly rents could sustain the practice. Most other broadcast functions have quite stable annual business activity levels.

As Central and Thames reduced permanent employment by half, their freelance component increased from eight to 40 percent and 11 to 31 percent of total employment, respectively, between 1985 and 1991. Freelance full-time equivalents increased from 152 to 378 at Central and from 278 to 338 at Thames over this period. Freelance employment grew in absolute terms in 14 of the 17 ITV companies, and increased markedly in terms of total employment percentages for all firms (Tables I and II). 
Figure 2: Freelance employment as a percentage of full-time employment for ITV Companies, 1983 and 1991

\section{Company}

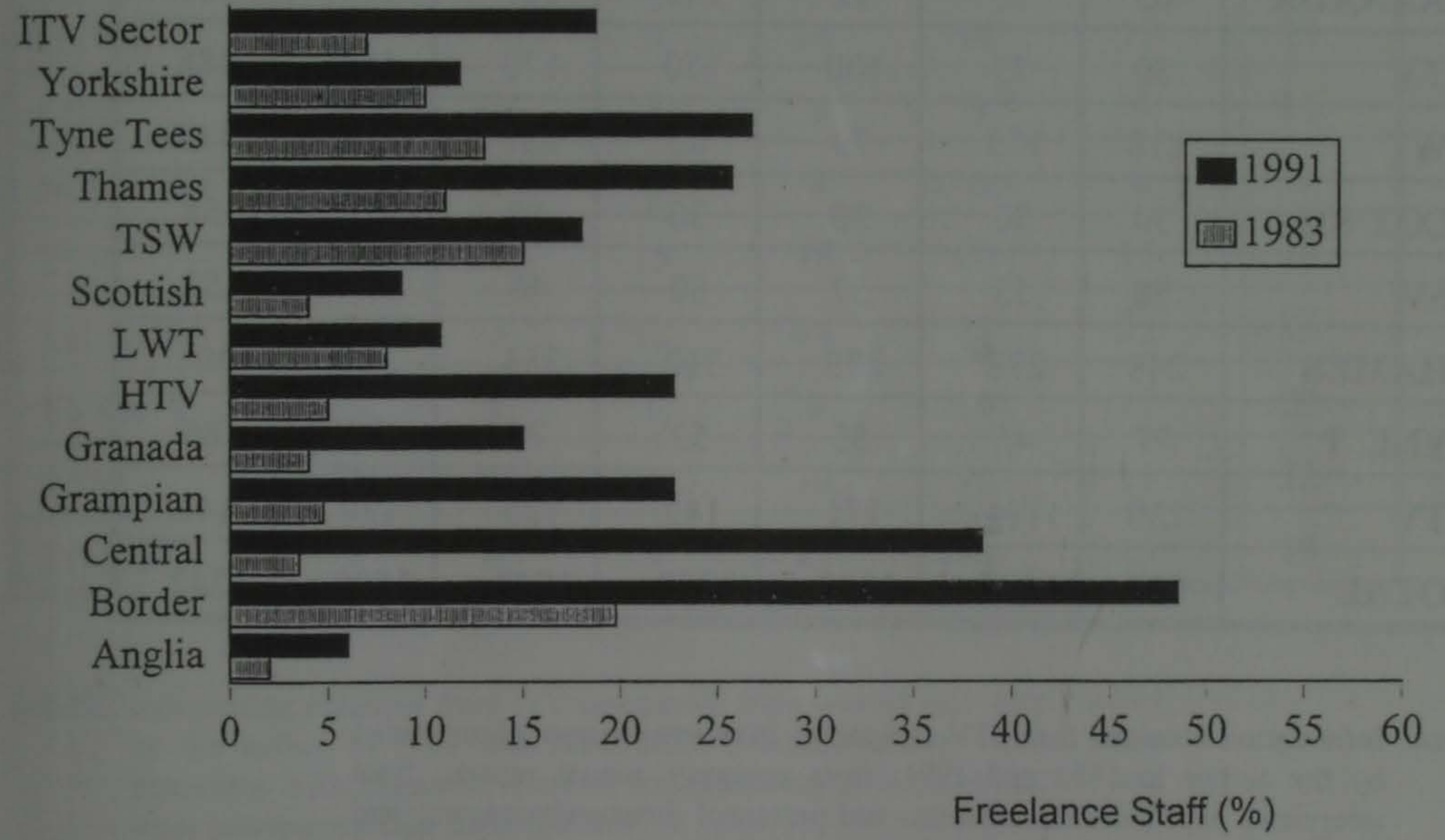

Source: Information obtained from ITV companies from two surveys administered by the author in 1989 and 1991, from company annual reports, from interviews with industrial relations and personnel directors/managers, and from newspapers and trade journals. 
Table I: $\quad$ Freelance worker use within ITV Companies, 1983-91 (full-time equivalents)

\begin{tabular}{||l|c|c|c|c|c|c|c||}
\hline $\begin{array}{c}\text { YEAR } \\
\text { COMPANY }\end{array}$ & $\mathbf{1 9 8 3}$ & $\mathbf{1 9 8 5}$ & $\mathbf{1 9 8 7}$ & $\mathbf{1 9 8 8}$ & $\mathbf{1 9 8 9}$ & $\mathbf{1 9 9 0}$ & $\mathbf{1 9 9 1}$ \\
\hline ANGLIA & 16 & 16 & 16 & 14 & 29 & 35 & 41 \\
\hline BORDER & 40 & 43 & 69 & 87 & 61 & 67 & 78 \\
\hline CENTRAL & 118 & 152 & 247 & 281 & 315 & 312 & 378 \\
\hline GRMPIAN & 12 & 10 & 18 & 32 & 39 & 38 & 45 \\
\hline GRANADA & 63 & 75 & 92 & 142 & 167 & 174 & 159 \\
\hline HTV & 50 & 75 & 100 & 150 & 170 & 166 & 188 \\
\hline LWT & 118 & 173 & 73 & 82 & 127 & 119 & 115 \\
\hline SCOT'SH & 30 & 30 & 30 & 30 & 40 & 51 & 58 \\
\hline TSW & 50 & 55 & 57 & 60 & 46 & 47 & 52 \\
\hline THAMES & 248 & 278 & 279 & 312 & 353 & 381 & 401 \\
\hline TYNE T & 77 & 45 & 55 & 53 & 76 & 80 & 86 \\
\hline YTV & 130 & 144 & 171 & 149 & 125 & 130 & 141 \\
\hline TOTAL & $\mathbf{9 5 2}$ & $\mathbf{1 0 9 6}$ & $\mathbf{1 2 0 7}$ & $\mathbf{1 3 9 2}$ & $\mathbf{1 5 4 8}$ & $\mathbf{1 6 0 0}$ & $\mathbf{1 7 4 2}$ \\
\hline
\end{tabular}

Source: Information obtained from ITV companies from two surveys administered by the author in 1989 and 1991, from company annual reports, from interviews with industrial relations and personnel directors/managers, and from newspapers and trade journals.

Two of the chief advantages for employers of contract based employment are, first, its provision of flexibility in terms of product demand fluctuation and its impact on employment and, second, its reduction in the full-time staff requirement and its associated costs (Williamson, 1975). Although the extensive use of contract labour has been commonplace in many capitalist enterprises since the emergence of industrial capitalism, it played only a very marginal role in British broadcasting prior to 1987 . The government's re-regulation of commercial broadcasting made increased external numerical flexibility an operational and economic necessity. Indeed, underlying the concept of "flexibility" is the imperative of labour cost control and containment, and it is in this respect the concept is reminiscent of the optimising behaviour of the firm in neoclassical economic theory (Rubery, Tarlington and Wilkinson, 1987). 
Table II: Freelance employment as a percentage of full-time

employment in ITV, 1983-91

\begin{tabular}{||l|c|c|c|c|c|c|c||}
\hline $\begin{array}{c}\text { YEAR } \\
\text { COMPANY }\end{array}$ & $\mathbf{1 9 8 3}$ & $\mathbf{1 9 8 5}$ & $\mathbf{1 9 8 7}$ & $\mathbf{1 9 8 8}$ & $\mathbf{1 9 8 9}$ & $\mathbf{1 9 9 0}$ & $\mathbf{1 9 9 1}$ \\
\hline ANGLIA & 2 & 2 & 2 & 2 & 4 & 5 & 6 \\
\hline BORDER & 20 & 20 & 32 & 39 & 28 & 37 & 49 \\
\hline CENTRAL & 6 & 8 & 13 & 15 & 18 & 20 & 39 \\
\hline GRMPIAN & 5 & 3 & 6 & 11 & 14 & 16 & 23 \\
\hline GRANADA & 4 & 5 & 7 & 11 & 14 & 15 & 15 \\
\hline HTV & 5 & 7 & 9 & 14 & 16 & 17 & 24 \\
\hline LWT & 8 & 10 & 4 & 5 & 9 & 9 & 11 \\
\hline SCOT'SH & 4 & 4 & 4 & 4 & 6 & 8 & 9 \\
\hline TSW & 15 & 17 & 15 & 16 & 14 & 15 & 18 \\
\hline THAMES & 11 & 13 & 12 & 14 & 18 & 22 & 26 \\
\hline TYNE T & 13 & 6 & 9 & 9 & 14 & 17 & 27 \\
\hline YTV & 10 & 10 & 12 & 10 & 10 & 11 & 12 \\
\hline TOTAL & $\mathbf{7}$ & $\mathbf{8}$ & $\mathbf{9}$ & $\mathbf{1 1}$ & $\mathbf{1 4}$ & $\mathbf{1 5}$ & $\mathbf{1 9}$ \\
\hline
\end{tabular}

Source: Information obtained from ITV companies from two surveys administered by the author in 1989 and 1991, from company annual reports, from interviews with industrial relations and personnel directors/managers, and from newspapers and trade journals.

Much of the literature on labour market flexibility argues that it creates a dual labour market in which the permanent, "core" employees are the most highly skilled and remunerated and the "periphery" of casual and part-time workers are semi-skilled and low paid (cf. Doeringer and Piore, 1971; Wilkinson, 1981). However, in commercial television there is no such clear delineation of worker types by skill between the "core" and the "periphery." Throughout ITV, casual workers perform highly skilled work alongside permanent, "core" employees. In fact, in some cases, freelance workers with specialised skills undertake "core" work that permanent staff are unable to perform. These include specialised computer graphics and animation, underwater and aerial filming, complex sound mixing for dramas, and specialist directing. Some of these casuals are former ITV permanent employees who accepted generous severance payments in the late 1980 s to become freelance workers. 
The notion that "core" employees are distinguished by their skill attributes is unsupported by the evidence from commercial television. In manufacturing, Pollert also notes that "it is now commonplace to observe that key skills can be and are brought in on a subcontract basis, and are often not part of a stable core" (1988: 297). The notion of "core" classified by the concept of skill is therefore untenable.

\section{Internal numerical flexibility}

Internal numerical flexibility concerns the quantity and timing of labour inputs such as flexible rostering, overtime and shiftwork.

Since the inception of the ITV network, the broadcasting unions had successfully maintained control over the internal labour deployment process. Rigid rostering, overtime and shiftwork rules were established by the unions, and tacitly accepted by the ITV companies, in order to guarantee stability, predictability, and uniformity in the administration of the employment relationship, in order to protect workers' rights and employment security. In the process, the companies relinquished day-to-day responsibility for many operating decisions. These had either become enshrined in formal agreements or were part of workplace custom and practice.

Even though many of the working practices that had accumulated over time had become outmoded because of changes in broadcasting technology, programme formats and studio layout, they nonetheless remained; protected by the "shelter" of ITV's monopoly over advertising. Management attempts to change them in the early 1980 s were largely unsuccessful.

When the balance of workplace power shifted rapidly in favour of management in the late 1980 s, three entrenched rules affecting internal labour deployment were abolished. These three practices, referred to in the industry as "golden hours", "ghosters" and "notionals", were established during the 1950s and 1960s and were not inconsistent with the demands and requirements of commercial television at that time. These penalty payment rules were rarely activated then because television production and transmission seldom went beyond midnight. Transmission times were restricted to 10 to 12 hour days, rather than the 18 to 24 hour services that were introduced in the late 1970s.

The "golden hours" agreement began to inflate labour costs dramatically from the mid1970 s. The agreement allowed technicians whose rostered period of duty started before midnight and continued beyond midnight to be paid at double time and a half until $1 \mathrm{am}$, then at triple time until $2 \mathrm{am}$ and finally four-and-a-half time beyond $2 \mathrm{am}$. If the working was not rostered it would be paid at a half time more for each of the times specified above. These rates contrasted with the UK engineering industry, where the average for all overtime has traditionally been one and a half times the basic rate.

"Ghosters" and "ghost working" occurred relatively frequently, especially when work was commissioned from independent producers. "Ghosters" provided studio electricians with pay, at double time, for the entire night if they worked beyond lam, even if it was only for 
a fraction of the night. During the 1980s many ITV companies increasingly signed special "buy out" agreements with the unions on specific projects to reduce the inflexibility and cost-push inflationary effect of the "golden hours" and "ghosters" rules.

A further fetter on flexible labour deployment and source of increased labour costs was the "notional". The notional was a theoretical day off for which all unionised broadcasting staff received double-time if they worked on that day. Labour costs could also rise if the tenhour break between shifts was breached, resulting in payment for the second shift at double the rate of the previous one. Successive breaching of the ten-hour break would result in an exponential increase in the hourly wage rate. This multiplying effect led to a TVam engineer legitimately accumulating $£ 92,000$ in overtime for three weeks work. He settled for $£ 10,000$.

Management and unions originally intended that these agreements would prevent excessively high levels of overtime working. However, as the unions cemented their control over workplace practices through supplementary local agreements it became increasingly apparent that rosters were being manipulated to guarantee overtime working. These workplace agreements allowed many senior technicians to earn more than salaried managers, in spite of their subordinate position. Senior technical grade incomes at the larger networks exceeded $£ 50,000$ in the mid 1980s (Independent Television Association, 1989).

Many ITV managers attributed these high incomes to "a conspiracy of greed" between the Association of Cinematograph, Television and Allied Technicians (ACTT) largely rightwing membership and its left-wing leadership. High incomes allowed the ACTT to charge a union subscription fee of one percent of income, which is considerably higher than the national average of 0.4 percent (Willman, 1990). However, management weakness and inaction, sustainable until the late 1980 s because of its television advertising monopoly, also allowed rigid and costly labour deployment practices to endure. Indeed, as one senior ITV industrial relations executive noted: "The trouble is that we've had pathetic managements in a monopolistic situation who have found it cheaper to buy their way out of trouble."

While ITV staff were always willing to work overtime and at weekends, this internal flexibility came at an extremely high price for the ITV companies in terms of penalty and premium payments. The abolition of these practices came swiftly between 1988 and 1990 , although for special productions and for the night service many companies had negotiated prior buy-outs in the mid 1980s. The Conservative Government's policy interventions, particularly the 25 percent independent quota, were effectively used by management at Thames and London Weekend Television to abolish "golden hours" and "ghosters" by threatening to use independent programme-makers rather than in-house staff. This management policy quickly spread through the ITV network.

With the abolition of centralised national bargaining in 1989 and the adoption of enterprise bargaining the companies established considerable control over internal labour deployment, with flexible rostering and labour deployment costs comparable to those elsewhere in British manufacturing - typically one-and-a-half to double time.

The national and international news provider for the network - Independent Television News (ITN) - abolished overtime, replacing it with an annualised hours system requiring 
1,836 hours or 155 shifts on a standard contract. In its first year of operation, coverage of the Gulf War stretched resources such that approximately 25 percent of technical and journalistic staff had worked their annual quota after nine months. The agreement made no provision for overtime, resulting in work intensification for those who were working. Of those who had prematurely worked their quota, approximately 50 percent continued to work without remuneration for the remainder of the year. Both management and unions agreed that such a dramatic shift in the payment system and the willingness of employees to work without pay would have been unimaginable prior to 1989 .

Yorkshire Television's (YTV) 1989 enterprise agreement allowed the rostering of staff up to 60 hours per week before overtime at 1.3 time was paid. In common with agreements at three other companies, the Granada contract consolidated many additional payments such as salary increments, productivity bonuses, and regular overtime payments, into a higher basic salary. Granada's emphasis on flexible internal staff deployment, coupled with costcontainment and the erosion of socially protective clauses, made it the most stringent in the network.

\section{Functional flexibility}

Functional flexibility refers to the ability of firms to reorganise jobs so that an employee's skills can be deployed across a broader range of tasks according to changes in demand, technology or marketing policy and is also associated with the development of new production concepts (Atkinson, 1987). This can involve grouping more tasks requiring the same skill level - horizontal loading - or clustering jobs of a higher or lower skill level vertical loading (Rubery, Tarling and Wilkinson, 1987; Marchington and Parker, 1990). Prior to 1988 , there was little flexibility for ITV managers to move employees between different functional tasks as business activity changed.

Since the 1950 s, custom and practice established a large number of clearly demarcated job functions, which were reflected in the 200 or more job classifications that existed within the larger ITV companies (Independent Television News, 1989). The intra- and inter-union job demarcations underpinned the minimum crewing provisions in drama, entertainment, and news and current affairs production. Both management and union officers agreed that from the 1960s to the mid-1980s most of the localised workplace disputes were over job demarcation. For example, a major television programme at London Weekend Television (LWT) was delayed for a week in the mid 1980s because of a dispute between the electricians union, the Electrical, Electronic and Plumbing Trades Union (EETPU), and the stage and scenery workers union, the Broadcasting and Entertainments Trades Alliance (BETA), over which group of workers should operate a revolving stage. Because it was driven by an electric motor, the electricians claimed jurisdiction over the work. However, BETA claimed that it was custom and practice for "stage" work to be undertaken by their members. All the ITV industrial relations managers reported that demarcation disputes accounted for much of their work until the mid 1980s.

The development of rigid job demarcations and the enforcement of minimum crewing levels in commercial television can be attributed to three factors. First, since the 1950s the ACTT, 
which organised all the technical grades in ITV, brought to commercial television a history of fighting employment insecurity in the film industry. The rules the ACTT had established in the film industry, to help protect jobs by limiting worker entry and upholding skill demarcations, protected their members' earnings, bargaining power and employment security.

Second, the technology was still very much in its infancy and subject to erratic and unpredictable behaviour. The crewing levels and skill demarcations were closely "calibrated" with this new and rather idiosyncratic technology. For example, quite often it was only the camera operators who understood the idiosyncrasies of their equipment. This specialised knowledge of the operational requirements of the different component technologies of broadcasting served to reinforce job demarcation.

Third, job demarcation also served an important workplace political role. The formalisation of these work rules symbolised worker resistance to managerial control over work. It is not surprising then that the broadcasting unions have historically opposed even minimal attempts at reducing workplace rules. The work rules operate as a barrier against discretionary and arbitrary decision making by managements. Crozier, in his study of bureaucracy, also notes the tactical invocation and interpretation of rules by workers to resist managerial control of the workplace (Crozier, 1964).

The rigid job demarcations gave way to various forms of functional flexibility throughout the ITV network from 1988 onwards. The dismantling of intra- and inter-union job demarcations affected all ITV companies but several companies imposed more revolutionary changes. For example, TVam, the national breakfast television provider for the ITV network, abolished all existing technical grades, replacing approximately 80 grades with a single technical operative grade. This accompanied a reduction in technicians from 230 to 70 , the frequent rotation of jobs for technical operatives, and the use of freelance, singleoperator crews for all news gathering. These changes followed the most bitter and protracted industrial dispute in British television broadcasting in which the company locked out and finally dismissed 229 technicians over a minimum crewing dispute in 1988. It was popularly seen as television's "Wapping"; viewed by the unions and many industry observers as a re-run of the bitter conflict between Rupert Murdoch's News International and the National Graphical Association (NGA) over the introduction of new technology and work practices in the newspaper industry in 1984. However, there are several important differences between the two disputes. Firstly, unlike the Wapping dispute, new technology was not an issue in the TVam dispute; the company had no intentions to automate the operation. While the ACTT often resisted new technology, it did so for different reasons than the NGA. For the NGA, computerised printing technology posed a substantial threat to employment security, whereas in television much of the new technology did not undermine job security. In fact, the ACTT welcomed new technology, but on its terms.

Secondly, unlike newspaper printing, the changes in television broadcasting have not completely changed the nature of work. Technicians perform a wider range of tasks, operate lighter and occasionally automated technology, but the tasks remain essentially unchanged. While TVam eliminated demarcations among technicians jobs, through creating a single technical operative grade, the manner in which the product is produced remained essentially unchanged. 
While most functional flexibility involved horizontal job loading in distinct functional areas, such as in news gathering and studio where vision, sound and lighting tasks became broadbanded rather than separate classifications, several companies went further. For example, ITN and TVam began training journalists, represented by the National Union of Journalists (NUJ), to edit their own videotaped news stories rather than use edit suite technicians, who were represented by the ACTT. This represented a significant challenge to the ACTT's jurisdictional workplace control. The ACTT, BETA and the EETPU tacitly accepted the erosion of inter-union job demarcation in allowing electricians to operate cameras and sound equipment, technicians to operate lights, and BETA studio grades to work video and lighting equipment.

The training and utilisation of journalists in technical areas drew criticism from the ACTT because it threatened employment security and programme quality. The journalists' union did not support this variant of functional flexibility because it was an attempt to combine quite distinct occupational tasks, with the opportunity for intensifying workloads for its members. In addition, it further threatened the already fragile relationship with the ACTT over the NUJ's failure to support the technicians during the TVam dispute. ITN and TVam began to introduce a limited form of this cross-functional working in 1992, despite union opposition.

Increased functional flexibility also enabled many of the ITV companies to install and operate new broadcasting technologies. For example, at Anglia Television, the film and electronic sections of the ACTT shop were merged under a single pay and conditions structure with the financial inducement of a four percent productivity payment for those with a minimum of five years experience. This allowed the company to roster any technician to operate its new computerised programme and commercials play-out-to-air machines (cart machines). Granada and Tyne-Tees imposed similar functional flexibility without any financial incentives, but with considerably less cooperation from the ACTT and staff.

\section{Wage flexibility}

Wage flexibility provides incentives to increase output through performance-related pay, such as piecework and bonus systems. Payment systems in ITV always rewarded on the basis of hours worked rather than actual productivity. This has been preserved in most of the new enterprise agreements since 1989. The companies focused on reducing total labour costs, particularly the overtime component.

Prior to the decentralisation of pay negotiations, minimum annual salaries for the 101 ACTT, 59 BETA, seven EETPU and 31 NUJ job grades was negotiated annually between each union and the ITVA. Supplementary local pay negotiations created substantial earnings differences between the companies. For example, at Central, LWT, Thames and YTV a senior camera operator earned about $£ 24,000$ per annum in 1989 , excluding overtime and penalty payments. Their counterparts at the other companies were earning $£ 16,000$ to $£ 19,000$ per annum (Independent Television Association, 1989). 
Under the enterprise agreements, salary increases averaged eight percent in 1989/90 and 5.8 percent in 1991, with the exception of HTV, ITN, TSW, Thames and Yorkshire who imposed pay freezes. However, the elimination of most penalty payments and the reduction of overtime rates brought labour costs down substantially. Estimates obtained from the ITV companies ranged from a four to 20 percent reduction in total labour costs.

Labour cost reduction was driven by the competitive pressures created by the introduction of the Government's new franchise auction system. Cost savings would allow higher bids to be made because there would be more financial resources for the initial cash payment and for the subsequent annual payments for the ten year franchise period. Consequently, the companies were more concerned with immediate and sustained cost reduction, rather than with wage flexibility.

Whilst most companies achieved cost reductions through extending the period over which the basic rate was paid from 40 to 60 hours per week, reducing paid overtime rates to 1.3 basic time and eliminating most penalty payments, three companies adopted defined working time contracts (annualised hours) instead. For Anglia, ITN and Yorkshire Television a defined working time contract tackled two basic management problems: inflexible human resource deployment and substantial overtime payments. ITN's Director of Industrial Relations declared that its purpose was to "squeeze overtime out of an organisation that had an endemic overtime culture". Overtime accounted for 15 to 45 percent of total earnings in ITV in the 1980s, with ITN and London Weekend Television (LWT) paying the largest proportions because of the unpredictability of news coverage and the largely weekend work schedule, respectively (Independent Television Association, 1989).

The benefits of fixed annual labour costs (contingent upon a predetermined freelance budget) and increased managerial discipline to use the fixed hours more effectively have been partially offset by several disadvantages. In addition to the premature utilisation of contract hours that occurred at ITN in 1990, all three companies have been unable to implement short-term labour cost savings because they are fixed for the year. Also, both management and union representatives reported that the system tends to discourage the use of labour. Whereas previously there was a tendency for supervisors and employees to create overtime opportunities there is now the opposite behaviour. ITN's Director of Finance complained that some departments were three to five percent under the 1991 annual quota, which meant that approximately $£ 1$ million worth of purchased labour time was not utilised and was unrecoverable.

While immediate and substantial cost reduction arrangements dominated the new enterprise agreements, YTV planned to introduce a pay-for-performance component to remuneration. The linking of remuneration to individual performance has been opposed by the newly formed Broadcasting, Cinematograph and Theatre Union (BECTU), following the amalgamation of the ACTT and BETA. With only two ITV companies conducting performance appraisals and a preoccupation with simple cost reduction, it is unlikely that wage flexibility will be introduced widely in ITV.

While only YTV plans to link pay to individual performance, LWT and Ulster introduced profit-sharing in order to partially link pay to organisational performance and to increase 
staff loyalty and commitment.

\section{Procedural flexibility}

The final type of labour market flexibility is procedural flexibility which includes consultation mechanisms such as joint consultative committees and various other forms of industrial democracy.

Prior to 1987 , the trade unions had considerable influence over technological change, work and safety issues, and contracting out through their participation in national and enterprise based joint consultative committees. Their ability to disrupt or halt broadcast transmission was used quite strategically to obtain their objectives in joint consultative meetings and annual national negotiations. The sudden shift in the balance of power to ITV managements since 1987, coupled with the financial pressures that threatened deregulation has exacted upon them, promoted unilateralism among managements. While Granada, ITN, TVam, and Tyne-Tees imposed many important workplace changes, the other companies frequently threatened to do so if agreement could not be reached. Prior to 1987 this style of negotiation would have resulted in immediate and damaging industrial action.

Managements' newly acquired power rendered consultative committees impotent and reversed the procedural flexibility that had dominated ITV industrial relations since the 1960s. In striving for greater external and internal numerical flexibility and functional flexibility, ITV managements have simultaneously driven procedural flexibility largely out of the workplace. The demise of procedural flexibility has been justified on the grounds that it impedes management's "right to manage".

The loss of the unions' status through managements' imposition of redundancies, casualisation and rationalised crewing levels have revealed the marked vulnerability of the unions. With union status severely weakened by the threat of marketisation and their inability to conclude a successful ending to the TVam dispute, managements throughout ITV abandoned genuine consultation with the union and proceeded to swiftly rationalise production.

The tearing up of the national agreements by ITV managements and their unilateral replacement with enterprise agreements diluted the status of the national executives of the broadcasting unions. They had always played a central role in negotiating the terms and conditions of the national agreements. Enterprise bargaining shifted this responsibility to local trade union officials who, in the face of unilateral decisions by management to dramatically reduce staff and casualise various jobs, wielded little negotiating power.

The unions' loss of status and power did not prompt managements to withdraw official recognition of the trade unions. In fact, the only broadcaster to derecognise a broadcasting union was TVam and this was viewed by all the other ITV companies as unhelpful and unnecessary. Thus, the introduction of "flexible" practices was not accompanied by an antiunion stance. The preservation of union organisation and collective bargaining in organisations with "flexible" working practices or "non-standard contracts" has been noted 
in other studies (for example, Hunter, et al., 1993). In the case of ITV, less than five percent of the managers interviewed for this study saw any substantial benefits from establishing a union-free workplace.

\section{Conclusions}

A number of important conclusions arise from this study. Perhaps the most important is the notion that it is political contingencies, rather than economic forces, that produced many of the changes in employment practices in British commercial television. Many writers have identified altered product markets and increased competition as the origins of workplace flexibility and the "new industrial relations". Indeed, the flexible firm literature traces flexibility to more competitive product markets. This paper has made a contrary argument that the "political contingency" was the main motor of change. Many of the important workplace restructuring activities, such as the introduction of multi-skilled technical operatives and casualisation, were introduced without any change to the industry's product market. It was the threat of a deregulated British television broadcasting industry that dramatically changed industrial relations and working practices in ITV. Unlike many of the contemporary arguments that stress economic determinism of employment practices, this article reveals that the origins of flexibility can be political.

The article draws some important conclusions about the extent and nature of the flexible practices introduced in commercial television. The new employment regime combines flexible and inflexible labour market practices. On the one hand, there is far greater external and internal numerical flexibility and functional flexibility whereas on the other hand, there is negligible wage flexibility and diminished procedural flexibility. The important point is that the industry has selected from the repertoire of flexible working practices and has failed to apply the full model. The newly acquired economic bargaining power of ITV managements has created this "asymmetrical flexibility", indicating that the distribution of workplace bargaining power is crucial in determining the mix of "flexible" and "inflexible" practices. The companies have selected those practices which they believe will win sufficient approval from the Government and that will deliver the financial performance needed to retain their franchises. These have included substantial redundancies for permanent employees, expanded casualisation and subcontracting, increased managerial control over rostering arrangements, and the intensification of work due to multi-skilling and crew size reductions.

While the "new" flexible labour market practices have produced productivity gains, the "inflexible" practices have determined how the fruits of increased efficiency are distributed. The emphasis on sustained cost reduction, with no linking of wages to efficiency gains, will ensure that the companies benefit financially from "flexibility". The near abandonment of procedural flexibility, which coincided with the shift in economic bargaining power to ITV managements since 1987 , has effectively muted workplace discussion of distributive issues. By reducing the opportunities for unions to question and contest their decisions, management has been able to impose and enforce flexible working practices. The lack of "procedural flexibility" reflected the shift in the balance of industrial relations power in management's favour. The companies wanted to restore management prerogative by 
simultaneously weakening contractual obligations on themselves, imposing contractual obligations on employees and reducing the influence of unions. For many managements this was their long awaited opportunity to take "revenge" on the broadcasting unions, which had wielded considerable industrial power through the 1970s and much of the 1980s. Thus, the lack of "procedural flexibility" was quite consistent with management's overall industrial relations strategy. This raises doubts about the analytical utility of the "procedural flexibility" concept.

The empirical evidence suggests that a majority of companies were implementing employment flexibility as part of a strategic change initiative. The larger firms published strategic change programmes in the late 1980s that set out their employment strategy for the coming decade. The "strategic" nature of the employment relationship changes is consistent with Atkinson's flexible firm model. This contrasts with evidence from other industrial sectors where increases in flexibility have been viewed as non-strategic and opportunistic in nature, representing an intensification of traditional approaches to the use of peripheral labour (e.g. Hakim, 1990; McGregor and Sproull, 1992).

The strategic introduction of employment flexibility has had generally positive consequences for the performance of the ITV companies. Other stakeholders have been less fortunate. The proportion of secure, full-time employment has diminished, nonmanagement incomes have decreased, and work intensification has accompanied multiskilling.

With both unions and industry commentators noting that production values are now less consistent than prior to the late 1980s, employment flexibility would appear to be reinforcing a lower-cost, lower quality equilibrium in British commercial television.

\section{References}

Annan Committee (1977), Report of the Committee on the Future of Broadcasting, London, HMSO.

Atkinson, J. (1984), Manpower Strategies for Flexible Organisations, Personnel Management, August: 28-31.

Atkinson, J. (1987), Flexibility or Fragmentation? The United Kingdom Labour Market in the Eighties, Labour and Society, 12(1): 87-105.

Atkinson, J. and Gregory, D. (1986), A Flexible Future: Britain's Dual Labour Market Force, Marxism Today, April: 12-17.

Atkinson, J. and Meager, N. (1986), Is Flexibility Just a Flash in the Pan? Personnel Management, September: 26-29.

Benko, G. and Dunford, M. (eds) (1991), Industrial Change and Regional Development: The Transformation of New Industrial Spaces, London, Belhaven Press. 
Campling, J. T. (1992), Competitive Shock and the Employment Relationship: A Study of the Transformation of Employee Relations in Commercial Television, 1985 to 1991, unpublished Ph.D., University of Cambridge.

Crozier, M. (1964), The Bureaucratic Phenomenon, London, Tavistock.

Davis, H. and Levy, C. (1992), Deregulation of Television: A British/West European Comparison, Economy and Society, 21(4): 453-482.

Doeringer, P. B. and Piore, M. J. (1971), Internal Labour Markets and Manpower Analysis, Lexington, Heath.

Dyson, K. and Humphreys, P. (1990), The Political Economy of Communications: International and European Dimensions, London, Routledge.

Ferner, A. (1985), Political Constraints and Management Strategies, British Journal of Industrial Relations, 23(1): 47-70.

Hakim, C (1990), Core and Periphery in Employer's Workplace Strategies: Evidence from the 1987 ELUS Survey, Work, Employment and Society, 4(2): 157-188.

Harvey, D. (1989) The Condition of Postmodernity, Oxford, Basil Blackwell.

Home Office (1988), Broadcasting in the '90s: Competition, Choice, and Quality, London, HMSO.

Hunter, L., McGregor, A., MacInnes, J. and Sproull, A. (1993), The "Flexible Firm": Strategy and Segmentation, British Journal of Industrial Relations, 31(3): 383-407.

Independent Television Association (1989), Annual Pay Survey, London, ITVA.

Independent Television News (ITN), Total Pay Plan, ITN, London, 1989.

Kochan, T. A., Katz, H.C. and McKersie, R.B. (1986), The Transformation of American Industrial Relations, New York, Basic Books.

McGregor, A. and Sproull, A. (1992), Employers and the Flexible Workforce, Employment Gazette, May: 225-234.

Marchington, M. and Parker, P. (1990), Changing Patterns of Employee Relations, London, Harvester Wheatsheaf.

Monopolies and Mergers Commission (1989), Labour Practices in TV and Film Making, A Report Under Section 79 of the Fair Trading Act 1973, Cm. 666, London, HMSO.

Peacock, A. (1986), Report of the Committee on the Financing of the BBC, London, HMSO. 
Pollert, A. (1988), The Flexible Firm: Fixation or Fact?, Work, Employment and Society, 2(3): 281-316.

Pollert, A. (ed.) (1991), Farewell to Flexibility? Oxford, Basil Blackwell.

Rimmer M. and Zappala, J. (1988), Labour Market Flexibility and the Second Tier, Australian Bulletin of Labour, 14(4): 564-591

Rubery, J., Tarling, R. and Wilkinson, F. (1987), Flexibility, Marketing, and the Organisation of Production, Labour and Society, 12(1): 131-151.

Sayer, R. A. and Walker, R. (1992), The New Social Economy: Reworking the Division of Labour, Oxford, Basil Blackwell.

Wilkinson, F. (ed.) (1981), The Dynamics of Labour Market Segmentation, London, Academic Press.

Williamson, O. E. (1975), Markets and Hierarchies: Analysis of Antitrust Implications, Glencoe, Free Press.

Willman, P. (1990), The Financial Status and Performance of the British Trade Unions, 1950 to 1988, British Journal of Industrial Relations, 28(3): 313-327. 